\title{
Chelating behavior of macroreticular hydroxamic acid resin towards molybdenum(VI), tungsten(VI), uranium(VI) and vanadium(V)
}

\author{
Chuen-Ying Liu and Peng-Joung Sun \\ Department of Chemistry, National Taiwan University, Taipei, Taiwan, Republic of China
}

\section{Komplexierungsverhalten von makroretikularem \\ Hydroxamsäureharz gegenüber \\ Molybdän(VI), Wolfram(VI), Uran(VI) und Vanadium(V)}

Zusammenfassung. Die Eigenschaften und das Verhalten von Hydroxamsäureharz wurden untersucht. Das Harz erwies sich als hochselektiv für Mo(VI), W(VI), U(VI) und V(V). Die Stabilitätskonstanten der Komplexe wurden bestimmt, die Sorptions- und Desorptionscharakteristica wurden untersucht und Trennungsmethoden für die genannten Ionen an einer kurzen Säule entwickelt.

Summary. The properties and behaviour of the hydroxamic acid resin have been studied and shown to be an highly selective resin for molybdenum(VI), tungsten(VI), uranium(VI) and vanadium(V) ions. The stability constants of these metal ion complexes with the resin have been determined. The sorption and desorption characteristics of these metal ions on this resin and the methods for the separation of these metal ions from each other on a short column of such resin were also developed.

\section{Introduction}

Hydroxamic acids contain the reactive group, $-\mathrm{CONHOH}$. They are well known as good extracting agents for a number of metal ions [1]. They were also successfully used for the colorimetric determination and selective extractions for various metal ions [2-4], such as vanadium, iron, molybdenum, titanium, mercury, copper and uranium etc. Accordingly, resins containing hydroxamic acid are expected to have very good analytical useage.

Research carried out so far on polyhydroxamic acid resin has dealt mainly with equilibrium studies [5], separation possibilities for transition metal species $[6,7]$, for gold and silver [8], and for thorium(VI) and uranium(IV) [9]. No reports have been found on the systematic investigation of the complexing behaviour of hydroxamic acid resin towards molybdenum(VI), tungsten(VI), uranium(VI) and vana$\operatorname{dium}(\mathrm{V})$.

Here, we describe the synthesis and analytical properties of a chelating resin in which hydroxamic acid is chemically bound to the macroreticular polyacrylonitrile divinylbenzene copolymer, and the application of this resin to the chromatographic separation of molybdenum, tungsten, uranium and vanadium.

Offprint requests to: Chuen-Ying Liu

\section{Experimental \\ Instrumentation and reagents}

A radiometer $\mathrm{pH}$ meter was used with saturated calomel (type K 401) and glass (Type G202B) electrodes, which were calibrated against Beckman standard buffer solutions of $\mathrm{pH} 4.00$ and 7.00. A Hitachi model 624 digital spectrophotometer connected to a Hitachi model $\mathrm{QD}_{15}$ recorder and $10-\mathrm{mm}$ quartz cells was used for all absorbance measurements. Infrared spectra were recorded on a Jasco IRA-I infrared spectrophotometer.

Analytical-grade chemicals were used throughout. The stock solutions of all metal ions were standardized by EDTA titration.

\section{Synthesis of the poly-hydroxamic acid resin}

Separate solutions of $140 \mathrm{~g}$ of hydroxylamine hydrochloride in $720 \mathrm{ml}$ of methyl alcohol, and of $112 \mathrm{~g}$ of potassium hydroxide in $280 \mathrm{ml}$ of methyl alcohol, were prepared at the boiling point of the solvent. Both were cooled to $30-40^{\circ} \mathrm{C}$ and potassium hydroxide solution was added with shaking to the hydroxylamine solution; any excessive rise of temperature during the addition was prevented by occasional cooling in an ice bath. After all alkali had been added, the mixture was allowed to stand in an ice bath for $5 \mathrm{~min}$ to ensure complete precipitation of potassium chloride. Hydroxylamine solutions thus obtained were used to prepare the chelating resin.

The hydrolyzed product of polyacrylonitrile-divinylbenzene copolymer was prepared by the procedure described previously [10]. The carboxylic acid resin was then converted to polyhydroxamic acid resin by heating a mixture of the resin and hydroxylamine prepared as above at $\mathrm{pH} 8-9$ at $70^{\circ} \mathrm{C}$ in methanol for $30 \mathrm{~h}$.

The final product was collected by filtration under suction and washed sequently with water, $0.5 \mathrm{~N}$ sulfuric acid, water and acetone.

\section{Resin characterization}

Water regain. The method of centrifuging [11] was used.

Hydrogen ion capacity. Total acidic hydrogen content was determined by back titration. A $0.2 \mathrm{~g}$ sample of the resin in the acidic form was added to $10.0 \mathrm{ml}$ of $0.1000 \mathrm{~N}$ sodium hydroxide. It was equilibrated for $2.0 \mathrm{~h}$ at room temperature with stirring. The effluent was collected by suction and the excess base determined. 
Procedure for the determination of acidity constants. Airdried resin in the hydrogen form $(0.200 \mathrm{~g})$ was shaken in polyethylene bottles for a period of $48 \mathrm{~h}$ with $2 \mathrm{M}$ potassium chloride solution containing different amounts of $0.10 \mathrm{M}$ sodium hydroxide at a constant ionic strength of $0.1 \mathrm{M}$. The total volume of the solution was kept at $25.0 \mathrm{ml}$.

Determination of resin-metal complexation as a function of $p H$. The studies of metal complexation behavior as a function of $\mathrm{pH}$ were performed in two ways. The one was performed with large excesses of metal ion compared to the amount of resin used, in order to observe the maxima in metal uptake as a function of $\mathrm{pH}$. In the other study, limited amounts of metal ion were used so that the $\mathrm{pH}$ ranges for quantitative metal uptake could be determined.

In both procedures, $0.300 \mathrm{~g}$ samples of $60 / 100$ mesh resin were weighed into $100 \mathrm{ml}$ polyethylene bottles. Metal ion solution of different $\mathrm{pH}$-values were prepared by adding the required amount of metal ion solution to a $100 \mathrm{ml}$ beaker along with $5 \mathrm{ml}$ of $1 \mathrm{M}$ sodium acetate and enough distilled, deionized water to come to a total volume of approximately $30 \mathrm{ml}$. The $\mathrm{pH}$ of the samples was adjusted with perchloric acid and/or sodium hydroxide to the desired value and then quantitatively transferred into a $50 \mathrm{ml}$ volumetric flask. The $\mathrm{pH}$ of the resulting solution was then measured.

Duplicate resin samples at each $\mathrm{pH}$ were then equilibrated with a $50.0 \mathrm{ml}$ volume of each particular metal ion solution. Following an equilibration period of seven days, the samples were filtered to remove the suspended resin particles. The amount of metal ion remaining in solution was then determined, after appropriate dilution, by spectrophotometry.

The spectrophotometric methods used were as follows:

1. A method using thiocyanate-ascorbic acid as reagent was used for molybdenum [12]. After color development and dilution, the absorbance of the solution was measured at $458 \mathrm{~nm}$. If an organic extractant (n-butyl acetate) was used, the absorbance was measured at $468 \mathrm{~nm}$.

2. A method using thiocyanate-stannous chloride as reagent was used for tungsten [12]. After color development and dilution, the absorbance of the solution was measured at $401 \mathrm{~nm}$. If an organic extractant (n-butyl acetate) was used, the absorbance was measured at $404 \mathrm{~nm}$.

3. A method using thioglycolic acid as reagent was used for uranium [13]. After color development and dilution, the absorbance of the solution was measured at $360 \mathrm{~nm}$.

4. A method using $1 \mathrm{M}$ sodium hydroxide as reagent was used for vanadium [14]. After color development and dilution, the absorbance of the solution was measured at $270 \mathrm{~nm}$

Procedure for the determination of stability constants. The procedure of Loewenschuss and Schmuckler [15] was followed to determine the stability constants of the resin for molybdenum(VI), uranium(VI) and vanadium(V). Different quantities of air-dried resin in the hydrogen form were placed into $100 \mathrm{ml}$ polyethylene bottles. To each bottle were added $50 \mathrm{ml}$ of solution containing varying amounts of metal ions into $100 \mathrm{ml}$ polyethylene bottles. To each bottle added $50 \mathrm{ml}$ of solution containing varying amounts of metal ions [from 0.25 mmole to 0.98 mmole in case of molybdenum(VI), from 0.35 mmole to 0.70 mmole in case of uranium(VI) and from 0.05 mmole to $0.15 \mathrm{mmole}$ in case of vanadium(V)] and varying quantities of the external complexing ligands, EDTA [from 0.6 mmole to 2.0 mmole for molybdenum(VI), from 0.6 mmole to 1.2 mmole for uranium(VI), and from 0.4 mmole to $1.0 \mathrm{mmole}$ for vanadium(V)]. The $\mathrm{pH}$ of the solution in cases of molybdenum(VI) and vanadium(V) was adjusted to ca. 2.0, and that of all uranium(VI)-containing solution was adjusted to ca. 5.3. After an equilibration period of seven days, the quantity of metal ion remaining in the solution was determined spectrophotometrically.

The equation used to determine $K_{\mathrm{MR}}$, the stability constant of the resin for the metal ion, was

$$
\log K_{\text {overall }}=\log K_{\mathrm{MR}}-\log K_{\mathrm{MY}}=\log \frac{[\mathrm{MR}][\mathrm{Y}]}{[\mathrm{MY}]}-\log [\mathrm{R}] \text {. }
$$

Stability of resins. A $0.5 \mathrm{~g}$ portion of the resin was shaken with $100 \mathrm{ml}$ of ionic strength $1.0, \mathrm{pH} 3.0,0.02 \mathrm{~N}$ ferric ion solution for two days, then filtered off and washed with water. The resin was poured onto the column, then washed with $\mathrm{pH} 3.0,1 \mathrm{M}$ acetate buffer, and the sorbed iron eluted with $5 \mathrm{M} \mathrm{HCl}$. After the acid treatment, the resins were washed first with $\mathrm{pH} 3.0$ acetate buffer and then with water until the washings were at a constant $\mathrm{pH}$ value $(\mathrm{pH} 3.0)$. The same procedures were repeated ten times and the sorption capacity for iron each time was determined.

\section{Separation procedures}

Molybdenum. The following procedure was used to separate molybdenum from non-interfering metal ions.

1. Before application of the sample to the column, allow $0.01 \mathrm{M}$ hydrochloric acid to flow through the column at $1 \mathrm{ml} / \mathrm{min}$ for $30 \mathrm{~min}$.

2. Inject the sample onto the column.

3. Allow $0.01 \mathrm{M}$ hydrochloric acid to flow through the column at $1 \mathrm{ml} / \mathrm{min}$ to separate the non-interfering ions from molybdenum.

4. Change the eluent to $0.5 \mathrm{M}$ sodium hydroxide- $0.5 \mathrm{M}$ sodium chloride at a flow rate of $1 \mathrm{ml} / \mathrm{min}$ to elute molybdenum.

Tungsten. The procedure used was the same as above, except the eluent was $4.0 \mathrm{M}$ ammonium hydroxide.

Uranium. The procedure used was the same as above, except the conditioning reagent was $1 \mathrm{M}$ acetate buffer ( $\mathrm{pH} 4.5$ ) and the eluent was $0.1 \mathrm{M}$ hydrochloric acid.

Vanadium. The procedure used was also the same as above, except the eluent was $0.1 \mathrm{M}$ sodium hydroxide.

Molybdenum(VI), tungsten(VI), uranium(VI) and vanadium $(V)$

The following procedure was used to separate the mixture of these ions.

1. Before application of the sample to the column, allow $50 \mathrm{ml}$ of $0.01 \mathrm{M}$ sulfuric acid to flow through the column at the flow rate of $1 \mathrm{ml} / \mathrm{min}$.

2. A solution containing about $0.0115 \mathrm{mmol}$ of each element in $10 \mathrm{ml}$ of $0.01 \mathrm{M}$ sulfuric acid was percolated through a column of $10 \times 0.6 \mathrm{~cm}$, i.d., of polyhydroxamic acid resin of $60-100$ mesh particle size.

3 . The solution was washed onto the column.

4. The weakly absorbed uranium was eluted with $0.1 \mathrm{M}$ hydrochloric acid, and the fractions were taken from the beginning of the absorption step. 
Table 1. Characteristic properties of polyhydroxamic acid resin

\begin{tabular}{ll}
\hline Particle size & $60-100$ mesh \\
Percent cross-linking & $5.8 \%$ \\
Water regain & $1.6 \mathrm{~g} \mathrm{~g}^{-1}$ \\
Nitrogen content & $1.76 \mathrm{mmole}^{-1}$ \\
Hydrogen ion capacity & $4.77 \mathrm{mmole}^{-1}$ \\
pK $_{\mathrm{a}}(-\mathrm{COOH},-\mathrm{CONHOH})$ & $5.23,6.47$ \\
Copper capacity $^{\mathrm{a}}$ & $0.40 \mathrm{mmole}^{-1}$ \\
Molybdenum capacity $^{\mathrm{a}}$ & $1.53 \mathrm{mmole}^{-1}$ \\
Tungsten capacity $^{\mathrm{a}}$ & $1.05 \mathrm{mmole}^{-1}$ \\
Uranium capacity $^{\mathrm{a}}$ & $0.50 \mathrm{mmole}^{-1}$ \\
Vanadium capacity $^{\mathrm{a}}$ & $0.64 \mathrm{mmole}^{-1}$
\end{tabular}

at $\mathrm{pH} 2.0$

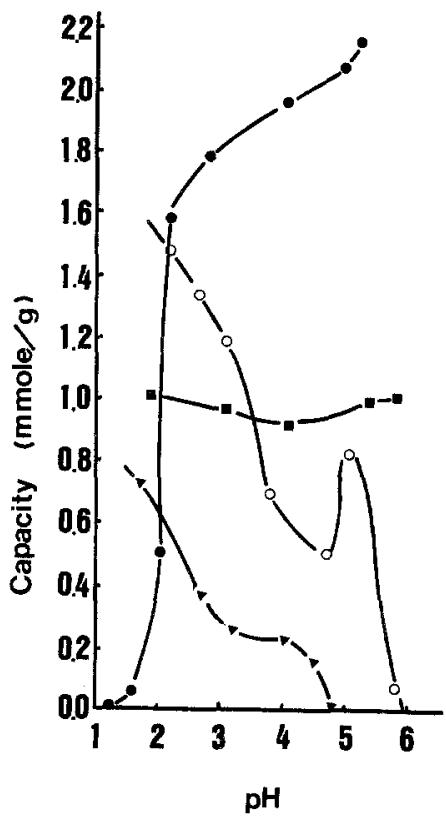

Fig. 1. Total capacity versus $\mathrm{pH}$ curves for metal ions on the polyhydroxamic acid ion exchanger. $\mathrm{Mo}(\mathrm{VI})\left(\mathrm{O} \_\right.$_- O); W(VI) $(\mathbf{\square}) ; \mathrm{U}(\mathrm{VI})(-\longrightarrow)$ - $\mathrm{V}(\mathrm{V})(\boldsymbol{\Lambda}-\mathbf{\Delta})$

5. Allow $0.5 \mathrm{M} \mathrm{H}_{2} \mathrm{SO}_{4}-0.1 \% \mathrm{H}_{2} \mathrm{O}_{2}$ to flow through the column to elute the sorbed vanadium.

6. Change the eluent to $3.0 \mathrm{M} \mathrm{H}_{2} \mathrm{SO}_{4}-0.1 \% \mathrm{H}_{2} \mathrm{O}_{2}$ to elute molybdenum.

7. Change the eluent to $4.0 \mathrm{M} \mathrm{NH}_{4} \mathrm{OH}$ to elute tungsten.

\section{Results and discussion}

\section{Characterization of resin}

In order to verify the presence of hydroxamic acid groups in the synthesized resin, the infrared spectrum of the resin was obtained with $\mathrm{KBr}$ pellets after each step in the synthesis. The i.r. spectrum of the polyacrylonitriledivinylbenzene copolymer showed bands at 2,260$2,240 \mathrm{~cm}^{-1} \quad(-\mathrm{C} \equiv \mathrm{N})$, whereas the spectrum of the hydrolyzed product exhibited bands at 3,500-2,500, 1,720 and $920 \mathrm{~cm}^{-1}(-\mathrm{COOH})$. The spectrum of the final product showed three peaks at $1,460-1,325 \mathrm{~cm}^{-1}(-\mathrm{CONHOH})$.

Elemental analysis gave $49.35 \% \mathrm{C}, 6.12 \% \mathrm{H}, 2.47 \% \mathrm{~N}$ and $42.05 \% \mathrm{O}$. The content of $2.47 \%$ of nitrogen means that each $1 \mathrm{~g}$ of resin contains $1.76 \mathrm{mmol}$ e of nitrogen or $1.76 \mathrm{mmol} e$ of hydroxamic acid functional group, since the
Table 2. Stability constants of molybdenum(VI), uranium(VI) and vanadium(V) with polyhydroxamic acid resin

\begin{tabular}{ll}
\hline Metal ion & Stability constant $(\log \mathrm{K})$ \\
\hline Mo(VI) & 6.6 \\
U(VI) & 8.3 \\
V(V) & 8.9 \\
\hline
\end{tabular}

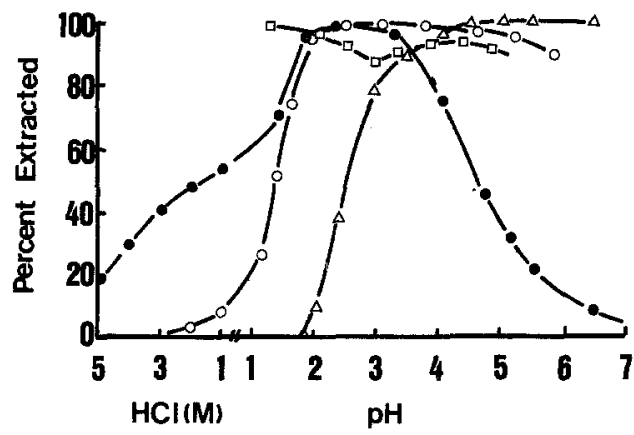

Fig. 2. Extraction of molybdenum(VI), tungsten(VI), uranium(VI) and vanadium(V) by polyhydroxamic acid resin vs. $\mathrm{pH}$. Amount of metal ion for each: $25.20 \mu$ mole. Amount of polyhydroxamic acid resin: $0.3 \mathrm{~g}$. Volume of solution; $50 \mathrm{ml}$. Mo(VI) (-_- $)$; W(VI) $(\square-\square) ; \mathrm{U}(\mathrm{VI})(\triangle-\triangle) ; \mathrm{V}(\mathrm{V})\left(\mathrm{O} \_\mathrm{O}\right)$

nitrogen content of the hydrolyzed product of polyacrylonitrile-divinylbenzene copolymer is below the detection level.

The water regain, the hydrogen ion capacity, the acid ionization constants and the capacities for Mo(VI), W(VI), $\mathrm{U}(\mathrm{VI})$ and $\mathrm{V}(\mathrm{V})$ at $\mathrm{pH} 2.0$ were determined with the results shown in Table 1.

The $\mathrm{pH}$ dependence of metal uptake using excess amounts of metal were performed on this resin. Of the metals studied, which include molybdenum(VI), tungsten(VI), uranium(VI) and vanadium(V), all showed a $\mathrm{pH}$ dependence of resin complexation as shown in Fig. 1.

The $\mathrm{pH}$ dependence of metal uptake at low metal concentrations showed a marked difference as compared to studies performed at higher metal concentration levels. The feature of this study to be noted was the $\mathrm{pH}$ range of quantitative metal uptake. Figure 2 showed the effect of $\mathrm{pH}$ on metal complexation for this resin at low metal concentration. The extraction curves indicated the possibility of separating uranium(VI) from the mixture of molybdenum(VI), tungsten(VI) and vanadium(V) using the polyhydroxamic acid resin.

During the course of the metal-resin study, a color change was observed for molybdenum(VI), uranium(VI) and vanadium(V). In the case of molybdenum(VI), the resin became increasingly more yellow as the test concentration increased. Uranium(VI) forms an orange color with the resin, while in case of vanadium( $(V)$ the resin color was pale violet at lower test concentrations and deep violet at higher test concentrations. No color change was observed for tungsten(VI).

The stability constants of the molybdenum(VI), uranium(VI) and vanadium(V) with polyhydroxamic acid resin are shown in Table 2 . The constants for the resin complexes agree fairly well with the corresponding constants of the hydroxamic acid monomer [16-18]. 
Table 3

Effect of the compounds on the sorption of molybdenum(VI), tungsten(VI), uranium(VI) and vanadium(V) on polyhydroxamic acid resin by the batch method $^{a}$

a Amount of metal ion for each: $36.75 \mu$ mole. Amount of polyhydroxamic acid resin: $0.3 \mathrm{~g}$. Volume of solution: $50 \mathrm{ml}$

b The sorption $\mathrm{pH}$ was 3.0

- Citric acid interferes in the determination method

\begin{tabular}{|c|c|c|c|c|}
\hline \multirow[t]{2}{*}{ Reagent } & \multicolumn{4}{|c|}{ Metal ion sorbed $(\%)$} \\
\hline & Mo(VI) & W(VI) & $\mathrm{U}(\mathrm{VI})$ & $\mathrm{V}(\mathrm{V})$ \\
\hline $0.1 \mathrm{M}_{\text {citric } \text { acid }^{\mathrm{b}}}$ & 15.48 & 38.44 & 20.54 & $<0^{\mathrm{c}}$ \\
\hline $0.5 \mathrm{M}$ citric acid ${ }^{\mathrm{b}}$ & - & 35.03 & - & - \\
\hline $0.1 \mathrm{M}$ ammonium tartrate ${ }^{\mathrm{b}}$ & 26.86 & 34.22 & 73.36 & 2.86 \\
\hline $0.1 \mathrm{M}$ potassium thiocyanate ${ }^{\mathrm{b}}$ & 93.88 & 49.99 & 76.11 & 25.71 \\
\hline $0.5 \mathrm{M}$ oxalic acid ${ }^{\mathrm{b}}$ & - & 53.06 & - & - \\
\hline $0.1 \mathrm{M} \mathrm{HCl}$ & 60.00 & 98.00 & 0.00 & 100.00 \\
\hline $3.0 \mathrm{M} \mathrm{HCl}$ & 40.00 & - & - & 0.00 \\
\hline $3.0 \mathrm{M} \mathrm{HClO}_{4}$ & - & - & - & 13.71 \\
\hline $0.1 \mathrm{M} \mathrm{NaOH}-0.2 \mathrm{M} \mathrm{NaCl}$ & 4.35 & 46.26 & pptn & 5.89 \\
\hline $0.5 \mathrm{M} \mathrm{NaOH}-0.5 \mathrm{M} \mathrm{NaCl}$ & 1.63 & 43.43 & pptn & 4.86 \\
\hline $0.5 \mathrm{M} \mathrm{H}_{2} \mathrm{SO}_{4}-0.1 \% \mathrm{H}_{2} \mathrm{O}_{2}$ & - & - & - & 12.57 \\
\hline $1.0 \mathrm{M} \mathrm{H}_{2} \mathrm{SO}_{4}-0.2 \% \mathrm{H}_{2} \mathrm{O}_{2}$ & - & - & - & 0 \\
\hline $3.0 \mathrm{M} \mathrm{H}_{2} \mathrm{SO}_{4}-0.1 \% \mathrm{H}_{2} \mathrm{O}_{2}$ & 30.20 & - & - & - \\
\hline $4.0 \mathrm{M} \mathrm{H}_{2} \mathrm{SO}_{4}-0.2 \% \mathrm{H}_{2} \mathrm{O}_{2}$ & 38.23 & $\sim$ & - & - \\
\hline $2.0 \mathrm{M} \mathrm{NH}_{4} \mathrm{OH}$ & - & 59.18 & - & - \\
\hline $4.0 \mathrm{M} \mathrm{NH}_{4} \mathrm{OH}$ & - & 19.51 & - & - \\
\hline $2.0 \mathrm{M} \mathrm{NH}_{4} \mathrm{NO}_{3}-0.5 \mathrm{M} \mathrm{NH}_{4} \mathrm{OH}$ & - & 98.94 & - & - \\
\hline $2.0 \mathrm{M} \mathrm{NH}_{4} \mathrm{NO}_{3}-4.0 \mathrm{M} \mathrm{NH}_{4} \mathrm{OH}$ & - & 97.82 & - & - \\
\hline
\end{tabular}

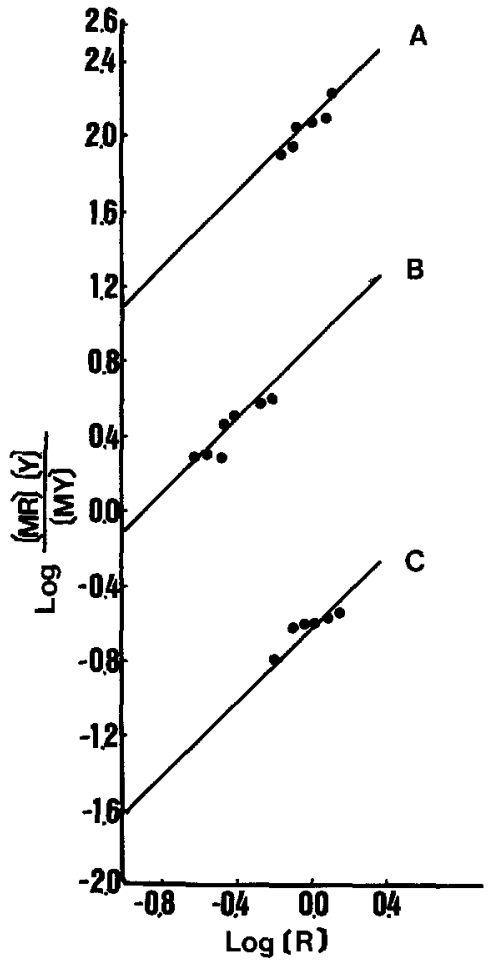

Fig. 3. Graphical determination of stability constants. $A$ U(VI) with polyhydroxamic acid resin; $B \mathrm{~V}(\mathrm{~V})$ with polyhydroxamic acid resin; $C \mathrm{Mo}(\mathrm{VI})$ with polyhydroxamic acid resin

The polyhydroxamic resin was completely stable to loading and acid washing with $5 \mathrm{M}$ hydrochloric acid. Iron(III) capacities with all values in ten determinations were between 1.70 and $1.90 \mathrm{mmole} / \mathrm{g}$.

The extraction curve for molybdenum(VI), tungsten(VI), uranium(VI) and vanadium(V) in Fig. 2 indicated the possibility of separating uranium(VI) from the mixture of molybdenum(VI), tungsten(VI) and vanadium(V) using the polyhydroxamic acid resin at $\mathrm{pH}$ 1.7. Under these conditions, uranium(VI) passed quantitatively through the column, molybdenum(VI), tungsten(VI) and vanadium (V) were strongly sorbed.

The choice of some reagents for the tested metal separations was due to the capability of forming chelates with these metal ions. The batch extraction data are listed in Table 3. They indicated that molybdenum(VI) could be eluted with $0.5 \mathrm{M}$ sodium hydroxide $-0.5 \mathrm{M}$ sodium chloride, tungsten(VI) with $4.0 \mathrm{M}$ ammonium hydroxide, vanadium(V) with $3 \mathrm{M}$ hydrochloric acid and uranium(VI) completely with $0.1 \mathrm{M}$ hydrochloric acid.

\section{Separation procedures}

Uranium(VI) was strongly retained on the column at $\mathrm{pH}$ 4.5 or higher, the sorbed uranium(VI) could be stripped completely from the column by $0.1 \mathrm{M}$ hydrochloric acid. Vanadium(V) could be sorbed completely on the column from aqueous solution of $\mathrm{pH} 1.0$ or higher to $\mathrm{pH}$ 3.5. With $3 \mathrm{M}$ hydrochloric acid as eluent, some vanadium(V) remains absorbed very strongly in the original band at the top of the column. This could be ascribed to the formation of polyvanadate. The sorbed vanadium could be eluted quantitatively with $0.5 \mathrm{M} \mathrm{H}_{2} \mathrm{SO}_{4}-0.1 \% \mathrm{H}_{2} \mathrm{O}_{2}$ (Fig. 4), but the use of $\mathrm{H}_{2} \mathrm{O}_{2}$ in the presence of vanadium(V) was not suitable for accurate work because vanadium(V) catalyzes the formation of gas bubbles. Molybdenum(VI) was absorbed on the column at $\mathrm{pH}$ values between 2.0 and 3.0. When molybdenum(VI) was absorbed from dilute $\mathrm{H}_{2} \mathrm{SO}_{4}$ or dilute $\mathrm{HCl}$ and then eluted with higher acid concentrations, only a part of the molybdenum(VI) was desorbed. The other part remains absorbed in the original band at the top of the column and appeared in the eluate in a continuous slow trickle. The reason for this lay in the tendency of $\mathrm{Mo}$ (VI) to form polynuclear species in solution [19]. Because a considerable concentration of Mo(VI) took place in a narrow band (yellow band) at the top of the resin column, it seemed reasonable to assume that an appreciable formation of polynuclear species of $\mathrm{Mo}(\mathrm{VI})$ could occur within 


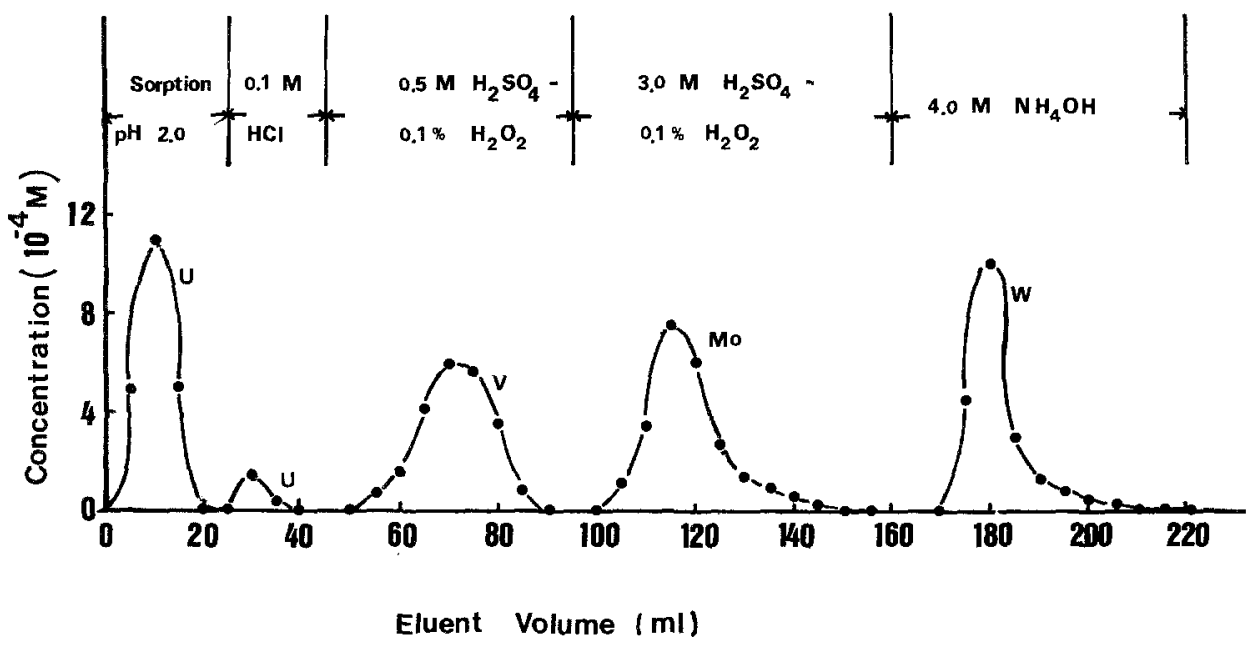

Fig. 4

Separation of molybdenum(VI) tungsten(VI), uranium(VI) and vanadium $(V)$ with polyhydroxamic acid resin column. Column: $10 \times 0.6 \mathrm{~cm}$ i.d.; Flow rate: $1 \mathrm{ml}$ $\min ^{-1} ; 12.25 \mu$ mole each of $\mathrm{Mo}(\mathrm{VI}), \mathrm{W}(\mathrm{VI}), \mathrm{U}(\mathrm{VI})$ and $\mathrm{V}(\mathrm{V})$ the resin particle, especially when the acid concentration was increased also. When $\mathrm{H}_{2} \mathrm{O}_{2}$ was present, the formation of large polymolybdate ions was suppressed by peroxide complex formation, although the values for the distribution coefficient in the presence of $\mathrm{H}_{2} \mathrm{O}_{2}$ were higher at high sulfuric acid concentrations than when $\mathrm{H}_{2} \mathrm{O}_{2}$ was absent. It is nevertheless possible to elute $\mathrm{Mo}$ (VI) quantitatively with $3.0 \mathrm{M} \mathrm{H}_{2} \mathrm{SO}_{4}$ containing $0.1 \% \quad \mathrm{H}_{2} \mathrm{O}_{2}$ (Fig. 4). When other elements were eluted, tungsten(VI) was retained and could be eluted with $4.0 \mathrm{M}$ ammonium hydroxide (Fig. 4).

\section{Conclusion}

Molybdenum(VI), tungsten(VI) and vanadium(V) were sorbed more strongly than uranium(VI) at more acidic region by the polyhydroxamic acid resin, so that uranium(VI) could be separated from the other ions mentioned at $\mathrm{pH} 2.0$ and the partially absorbed uranium(VI) was eluted completely with $0.1 \mathrm{M}$ hydrochloric acid. Since molybdenum(VI) and vanadium(V) occur in uranium-bearing ores, the possibility of extending the use of this resin from analytical separations to larger scale processing of nuclear fuels should certainly be considered.

Acknowledgements. This work was supported by a grant from the National Science Council of the Republic of China, to which great thanks are due.

\section{References}

1. Majumdar AK (1972) N-Benzoylphenylhydroxylamine and its analogues. Pergamon Press, New York

2. Stary J (1964) The solvent extraction of metal chelates. Pergamon Press, New York

3. Chappelow CC, Engel JF (1974) US Patent 3, 825, 585

4. Gasparini GM (1979) Proc Int Solvent Extr Conf 1977, 2654

5. Vernon F, Eccles H (1976) Anal Chim Acta 82:369

6. Vernon F, Eccles H (1976) Anal Chim Acta 83:187

7. Vernon F (1982) Pure Appl Chem 54:2151

8. Vernon F, Wan MD Z (1981) Anal Chim Acta 123:309

9. Phillips RJ, Fritz JS (1982) Anal Chim Acta 139:237

10. Liu CY, Sun PJ (1981) Anal Chim Acta 132:187

11. Pepper KW, Deichenberg D, Hale DK (1952) J Chem Soc 3129

12. Sandell EB (1959) Colorimetric determination of traces of metals, 3rd edn. Interscience Publishers, New York

13. Davenport WH Jr, Thomason PF (1949) Anal Chem $21: 1093$

14. Gottlieb IM, Hazel JF, McNabb WM (1954) Anal Chim Acta $11: 376$

15. Loewenschuss H, Schmuckler G (1964) Talanta 11:1399

16. Rowland R, Meloan CE (1964) Anal Chem 36:1997

17. Baroncelli F, Grossi G (1965) J Inorg Nucl Chem 27:1085

18. Majumdar AK, Das D (1964) Anal Chim Acta $31: 147$

19. Püschel R, Lassner E (1967) Chelates and chelating agents in the analytical chemistry of molybdenum and tungsten. In: Flaschka HA, Barnard AJ Jr (eds) Chelates in analytical chemistry, vol 1. Marcel Dekker, New York

Received December 20, 1985 